\title{
Forum
}

\section{Writing in Political Science}

It was with considerable embarrassment but even greater delight that I received a package from Prof. Diane E. Schmidt (Southern Illinois University at Carbondale) containing her recently published Expository Writing in Political Science: A Practical Guide (HarperCollins, 1993). Only its recent vintage prevented my including-nay, even creating a separate category for-Professor Schmidt's book in my article "Writing in Political Science" (PS, September 1993).

Building upon Ken Holland's pioneering work (Writer's Guide: Political Science (D.C. Heath, 1987), Prof. Schmidt has provided a comprehensive guide to writing in political science courses and even beyond, with material on resumes and job applications. Her text is particularly strong on topic selection and research methods, but has equally excellent chapters on critical thinking and formats for all types of political science papers (from annotated bibliographies to research proposals). Sample student papers are included as is a self-contained "casebook" for a clipping thesis. The text is available with an Instructor's Manual and a computer disk.

Prof. Schmidt's book is, in my view, a contribution not only to the pedagogy of political science but to the discipline of political science as well, resting as it does on a careful, systematic analysis of the kinds of research and writing that political scientists do.

David Z. Londow

Miami, FL

\section{Reply to Dye \& Zeigler}

I was glad to see in their " $\mathrm{Re}$ sponse to Kinnucan" that Thomas R. Dye and Harmon Zeigler (PS
March 1993) had some positive comments regarding my September 1992 PS article, "Political Economy and Militarism." On balance, though, it is clear that the main thrust of Dye and Zeigler's response is negative.

First, they assert that in reading my piece one must "wade through a swamp of Marxist polemics." This is a curious characterization since the data and conclusion do not support a hypothesis that capitalist states are more militaristic than socialist states. Probably, where Dye and Zeigler find fault is with my refusal to accept, unqualifiedly, the conventional wisdom that the former Soviet Union, China and the rest of the so-called Marxist countries have or had socialist politico-economic systems.

Second, Dye and Zeigler raise questions about the validity and reliability of my dependent variable of militarism-" number of involvements in armed conflict, 1945-89." Regarding the validity of my dependent measure, I agree wholeheartedly with Dye and Zeigler when they say that "a system that assigned weights (deaths, time, number of troops?) would be preferable." In fact, I acknowledged in my article (p. 508) that the strength of my analysis was, indeed, moderated by not accounting for the very factors that Dye and Zeigler mention. Nonetheless "number of armed conflicts" remains a valid measure of militarism, or better yet, war proneness.

A more serious criticism they make concerns the reliability of my data. As with most attempts to quantify social science phenomena the information I compiled and presented is undoubtedly less than 100 percent complete and accurate. However, of the cases questioned by Dye and Zeigler, their criticism is without merit in all but one.

Regarding the former U.S.S.R., Dye and Zeigler pointedly charge that I do not record as an involve- ment in armed conflict the systematic murder of political prisoners in Soviet gulags and psychiatric hospitals. They are correct. However, as in other instances-like the political killings by the pro-American Shah of Iran's secret police-I left this involvement in armed conflict out of my data set because I found no documentation, in the fifteen sources I cited, that it had resulted in 1000 or more deaths. The omission is, thus, the result of a well-reasoned and consistently applied coding rule.

Claiming, "No lives were lost" Dye and Zeigler find fault with my counting the 1968 civil disturbances in France as an involvement in armed conflict. While it is conceivable that the number of deaths fell short of 1000 it seems certain that many lives were lost. In Major Armed Conflict, published by the Canadian Department of National Defence, researchers G. D. Kaye, D. A. Grant and E. J. Edmond cite the figure of 3000 as the death toll from the 1968 political violence in France. This finding of more than 1000 deaths was corroborated by other sources cited in my article.

Another inexplicable criticism Dye and Zeigler make is that in my data set 'open societies get 'docked' for repression of 'civil insurrection' while closed ones, who [sic] do not tolerate unrest come out OK." In point of fact, such presumably "closed" societies as Burma, China, Iran, Kampuchea and South Yemen, among others, do indeed get " 'docked' for repression of 'civil insurrection" " in my data set.

Finally, Dye and Zeigler end their response with a confession"Like all who wish for human betterment, we await, and await, and await, the coming of the true socialist utopia."

Michael J. Kinnucan

Sacramento, $C A$ 


\section{Opposition to APSA's Domestic Partners Policy}

It is with a heavy heart that I resign herewith from a 24-year membership in the American Political Science Association for two reasons: (1) affirmative discrimination; and (2) moral perversion, as reflected in the September 1993 PS article, "APSA Extends Family Memberships to Include Domestic Partners" (p. 591). I do mourn for many friends and colleagues whose professional obligations, if not livelihood, restrain them from joining me in moral protest of the path of APSA in particular and American higher education in general. My "last request" is that you print this "farewell letter."

1. Little further needs to be said concerning "affirmative discrimination," an appropriate term coined by Nathan Glazer in his 1975 book bearing the same title, and confirmed by such minority scholars as Shelby Steele, The Content of Our Character (1990) and Dinesh D'Souza, Illiberal Education (1991). While the aspirations of "affirmative action" are laudable, the methods of quotas, reverse discrimination, etc. are not. The very notion of equality should be based on the sole criterion of the pursuit of life, liberty, and happiness without regard to race, color, religion, sex, national origin, or political persuasion. This is the definition of true freedom and true equality enshrined both in the U.S. Declaration of Independence and the Constitution. In contrast, "affirmative action" policies have resulted in a racial, ethnic, and gender spoils system in America, in and out of academe, which are laying the foundations of legally sanctioned discrimination for the next two centuries-breeding contempt for the law in general-whose ultimate result may well be "ethnic cleansing" and civil war just like in the former Yugoslavia. As the saying goes, those who sow the wind shall reap the whirlwind.

2. The 1993 APSA Meeting in Washington, D.C. was notable for two anomalies: (a) the abstruse irrelevance of much of the overall program; and (b) the proliferation of gay/lesbian and radical feminist agendas, as well as the distribution of the obscene questionnaire by the APSA Committee on the Status of Lesbians and Gays in the Profession, reprinted in PS (Sept. 1993), pp. 593-94. A critique of radical feminism as anti-women, antiintellectual, and anti-civilization may be found in Camille Paglia's tour de force, Sexual Personae (1990).

Of far more consequence is APSA's moral myopia in sanctioning, rather than condemning, sexual perversion of so-called gays and lesbians in its own ranks, if not in society as a whole. There is, of course, nothing "gay" about gay and lesbian sexual preferences or would-be "life-styles," which run counter to both common sense and Nature, as well as all three major monotheistic religious traditionsJudaism, Christianity, and Islam. Thus, both the Old and the New Testaments condemn such sexual perversions as "abominations" (Leviticus 18: 22; 20: 13; Romans 1: 26-27).

But, even those who may not fear a transcendent God of the Universe, may pause at the statistics regarding AIDS, since intravenous drug users and homosexuals represent the primary carriers and victims of the deadly disease. And public schools would do better to teach a little morality and abstinence, rather than hand out condoms and teach 12-year-olds the finer points of sex. Apart from moral and religious wrongs, condoms cum sex education as a substitute for morality, and monogamous bi-sexual relationships sanctioned by marriage, is also poor medical advice, since French researchers admit that condoms do not protect against AIDS, while everyone knows that 12 -year-olds should study academic subjects, including math and foreign languages (and much more intensively than they are required now), rather than sex.

I can no longer in good conscience remain a member of a professional association which is regressing to a pre-civilized moral state. Leo Strauss's famous critique of the behavioral persuasion in political science may also sum up APSA's current predicament. To wit: The new behavioral science of politics fiddles while Rome burns. It is excused by two facts: it does not know that it fiddles; and it does not know that Rome burns. But, America is burning and its youth is at sea morally, reflected in, and abetted by, the criminalization of culture in America, from TV sitcoms, crime news, and gang fashions to graffitti, hood(lum)s, and drug-rap-wilding. APSA members should ponder their responsibility to those who may grow up as savages, that is, moral pygmies. And, do not blame "society," if you help deconstruct it.

Praying for the Lord's guidance in our life and work,

Oskar Gruenwald
Institute for Interdisciplinary
Research

\section{Committee Reply to Gruenwald}

I am responding to Oskar Gruenwald's letter in my capacity as chair of the APSA's Committee on the Status of Lesbians and Gays in the Profession, since he resigns, in part, due to the existence and activities of the committee. This committee was established in 1992 by the APSA Council because, after study by a task force on the topic, it found significant questions regarding the academic freedom of, discrimination against, and collegiality toward lesbian and gay political scientists.

Through establishing the committee, the APSA recognized a longstanding problem and created a mechanism for addressing it. Some of the charges to the committee by the council included: articulating and promoting a policy of nondiscrimination and collegiality toward lesbians and gays; insuring that research about lesbian and gay politics be treated nonprejudicially as compared with other areas of political inquiry; encouraging inclusion of lesbian and gay politics where relevant within political science curricula; and conducting an empirical study of the current status of 
lesbians and gays in the profession for report to the council and distribution to the membership (PS, September 1992). These issues concerning the status of members of our profession had been raised previously by the Gay and Lesbian Caucus; similar committees in other social science and humanities professional associations have existed for a number of years to educate and recommend remedies to their members.

The questionnaire distributed at the 1993 Annual Meeting and published in PS (September 1993) was designed in tandem with a survey of department chairs. The goal is to measure the extent to which lesbian and gay political scientists are treated equitably within the profession and then to educate members about this status. Indeed, members have commented that the survey instrument is itself educational and suggestive of needed changes in attitudes and institutional policies. For many, especially, but not limited to lesbian and gay political scientists, the anonymity of the questionnaire allows for disclosure that might have been personally difficult or even dangerous in view of the possibility of professional reprisal.

The growth of the Gay and Lesbian Caucus as well as the sheer diversity of topics discussed at APSA Annual Meetings is testimony to the increasingly robust health of the discipline. A group of lesbians and gays has been meeting at the Annual Meeting at least since 1984 , but was only organized as a caucus in 1988. In other disciplines, gay and lesbian studies is organized as a section or as a field within the discipline, sometimes with its own representative on the governing body. The APSA caucus's membership has grown and so has its number of panels-from three in 1989 to nine in 1993 (often co-sponsored with other APSA entities). This growth of knowledge and the openness of the Annual Meetings has meant that the many different ideas of political scientists have been able to be exchanged and to benefit from exposure to each other.

Finally, after establishing the committee, the council took its first step toward realizing the committee's charge by extending domestic partner benefits to the benefits package offered APSA members as well as staff members. This step is aptly summed up by a remark an APSA staff member made to me: "We not only study equity, but we also seek to practice it."

Mark Blasius

City University of New York

\section{On the Motor Voter}

Errors of data and logic in the report by Calvert and Gilchrist in the December 1993 issue of PS suggest some cautions to analysts who try to assess the impact of the National Voter Registration Act (NVRA) of 1993. The core provision is that citizens will be offered the opportunity to register to vote when they get or renew drivers' licenses, or what is popularly called "motor voter."

Calvert and Gilchrist claim that state-level motor voter programs fail to raise registration and turnout, and they rely in part on a 1990 report by the Congressional Research Service (CRS). Unfortunately, CRS did not conduct field studies of motor voter arrangements; it merely canvassed state laws. But there is many a discrepancy between law and implementation, as we showed in a report rebutting CRS based on extensive field work in the states conducted by our staff at Human SERVE (the national voter registration reform organization). Of the ten so-called motor voter states surveyed by CRS,

(1) three states had motor voter programs on the law books that weren't yet operating;

(2) one state, North Carolina, began a motor voter system in 1984 , but virtually suspended it when a Republican won the governorship, and only resurrected it after a Democrat regained the statehouse beginning in 1989 (one year after the 1988 election which CRS used as its benchmark), with these year-by-year variations in motor voter registration totals:

$\begin{array}{rr}1984 & 60,000 \\ 1985 & 6,500 \\ 1986 & 6,200 \\ 1987 & 3,200 \\ 1988 & 3,300 \\ 1989 & 36,800 \\ 1990 & 84,000 \\ \text { two states only registered }\end{array}$

(3) two states only registered new applicants for drivers' licenses, and not the far larger pool of in-person renewals; three states allowed people to renew licenses by mail, but none registered these renewals to vote;

(4) and only one state (Michigan) had a motor program that had run through a full four-year drivers' license renewal cycle. Two states had only started up motor voter programs in 1988, the year of the CRS evaluation.

To sum up, a valid evaluation of the impact of motor voter on registration and voting must be limited to programs that are operational over a four-year cycle, and that, in addition to new applicants, register both in-person and mail renewals. Considering that only two states came close to meeting these criteria in 1988, CRS ought to have concluded that a valid evaluation of motor voter programs was not yet possible.

The second caution concerns logic. Calvert and Gilchrist claim that the emphasis on motor voter in the National Voter Registration Act is a mistake. Instead, they argue that "shortening the [30-day] deadline for personal registration or eliminating it altogether [i.e., permitting people to register on election day]" would be a more effective way to raise registration and turnout. That conclusion is illogical, or at least the logic is less than obvious. The point of shortened deadlines, or of day-of-election registration, is to allow people to register who become motivated to take the trouble by the intense publicity in the last days of political campaigns. If that is the case, why wouldn't a system that largely eliminates the trouble of registering be even more effective?

If the states comply with the federal bill, more than $90 \%$ of the eligible electorate will be offered the chance to register to vote when 
they get or renew drivers' licenses. According to the U.S. Department of Transportation (DOT), only 75\% of voting age adults held drivers' licenses in 1969. The figure rose to $81 \%$ in 1977 , to $84 \%$ in 1983 , to $87 \%$ in 1988 , and to $91 \%$ in 1992 . To this figure must be added nondrivers who apply for photo IDs, since they would also be registered in motor voter programs. The DOT does not collect statistics on personal IDs, and only a few states keep them. We found that $2.5 \%$ of the voting age population had IDs in South Carolina; $5 \%$ in both Maryland and Michigan; and $8 \%$ in Louisiana. If we make a seat-ofthe-pants estimate that $3 \%$ of the national voting age population have personal IDs, that raises the total who could potentially be registered in drivers' license bureaus to $94 \%$ in 1992.

Furthermore, the address-updating feature of motor voter programs can keep people registered despite high residential mobility. For example, Michigan motor voter officials reported a total of 772,161 voter registration transactions in drivers' license bureaus in 1984. Of these, 266,000 were new registrationspeople coming of voting age, residents who had not voted previously, and new residents from outof-state. And 506,000 of these transactions, or $65 \%$, were address updates by people who have moved within the state and who were renewing their drivers' licenses. The point is that if the National Voter Registration Act is vigorously implemented, everyone will have an easy opportunity to register and stay registered, making the issue of registration deadlines irrelevant. It should also be noted that Congress was unlikely to enact a bill mandating election-day registration, if only because most local election clerks adamantly oppose this reform for fear of logistical chaos that could result on election day.
A final cautionary note. Few states will have implemented the federal bill by the 1994 midterm elections. Analysts planning to report post-election results should take care in defining motor voter states to ensure that there has been full implementation. Similar care should be taken in reporting results from the 1996 presidential election. The federal bill does not require states to have motor voter programs up and running until January 1995. Even if all states comply by that date, the full impact of motor voter would not be known until the system runs through a full fouryear drivers' license renewal cycle, ending in 1998.

Francis Fox Piven

Graduate School and University Center City University of New York

Richard A. Cloward

Columbia University 